\title{
Prevalence of Acute Malnutrition And Associated Factors Among Children under Five Years of Age in Rural Kebeles of Shashemene Woreda West Arsi Zone, Oromia Regional State, Ethiopia, 2018
}

Aschalew Gatiso Endale ( $\nabla$ aschalewendale05@gmail.com )

Oromia Regional Health Bureau https://orcid.org/0000-0003-3250-4660

Degfachew Ararso Debela

Mena Regional: Mena Regional Health System

Teresa Kisi

Arsi University

Abebe Ferede

Arsi University

Niguse Shiferaw

Mizan-Teferi Teachers College: Mizan-Tepi University

\section{Research Article}

Keywords: Acute-Malnutrition (wasting).

Posted Date: April 14th, 2021

DOI: https://doi.org/10.21203/rs.3.rs-397320/v1

License: (c) (1) This work is licensed under a Creative Commons Attribution 4.0 International License.

Read Full License 
PREVALENCEOFACUTE MALNUTRITION ANDASSOCIATED FACTORS AMONG CHILDREN UNDER FIVE YEARS OF AGE IN RURAL KEBELES OF SHASHEMENE WOREDA WEST ARSI ZONE, OROMIA REGIONAL STATE, ETHIOPIA, 2018

Aschalew Endale*( aschalewendale05@ gmail.com)

Degfachew Debela (degfachewd@gmail.com)

Teresa Kisi (terek7@gmail.com)

Abebe Ferede (abebeferede027@gmail.com)

Nigusie Shifera (nigusieshifera@gmail.com)

* Corresponding Author

${ }^{1}$ Public Health Department, West Arsi Zonal Health, Oromia Regional Health beuro, Shashemene, Ethiopia

${ }^{2}$ Public Health Department, Ethiopian public health institute, Harare regional health beuro, Harar, Ethiopia

${ }^{3}$ Department of Epidemiology and Biostatics, School of Public Health, Arsi University, Asella, Ethiopia

${ }^{4}$ Department of Nutrition, School of Public Health, Arsi University, Asella, Ethiopia

${ }^{5}$ Epidemiology and Biostatics department, School of Public Health, Mizan-Tepi University, Mizan-Aman, Ethiopia 


\section{ABSTRACT}

Background: Acute malnutrition is a devastating public health problem. Globally about, 52 million underfive years old were wasted. One-third of these children live in Africa and Ethiopia is the seventh country among the ten top countries in which wasting is concentrated and currently $10 \%$ of under-five children are wasted. Although Ethiopia is implementing different nutritional interventions, but the prevalence of wasting is increasing and there is no scientific study done previously in the study area. So this study aimed to assess the prevalence of Acute Malnutrition and associated factors among children under five years in Rural Kebeles of Shashemene District, West Arsi Zone, Oromia Regional State, Ethiopia, 2018.

METHOD: A community based cross-sectional study design with multi stage sampling technique was conducted from July 1-30/2018 on a total of 457Mothers/caretakers of under-five children were interviewed using structured questionnaire and anthropometric measurements of the children were taken using standard procedures. Epi info version 7 was used for data entry and cleaning and SPSS version 21 was used for analysis bivariate and multivariate logistic regression were used to determine the association between dependent and independent variables. World Health Organization (WHO) Anthro software was used to convert nutritional data indices.

RESULT: The prevalence of wasting was 91(19.9\%) with 95\%CI. Mothers with no Antenatal Care (ANC) visits $(\mathrm{AOR}=2.26,95 \% \mathrm{CI}$ 1.14-4.46), mothers who had no autonomous in decision making ( $\mathrm{AOR}=2.42$, 95\%CI 1.42-4.12), children with diarrheal disease in the last 2 weeks preceding the survey(AOR=2.07,95\%CI 1.19-3.59)and deprive colostrum's ( $\mathrm{AOR}=1.99,95 \% \mathrm{CI}$ 1.07- 3.71) were had high risks for Acute malnutrition of their children's.

CONCLUSION AND RECOMMENDATION: This finding showed that, the prevalence of wasting is high; Mothers who had no power in decision making, squeezed out and throw colostrum's, Mothers who had no ANC visit, child's history of Diarrhea in the last two weeks were independent determinants of acute malnutrition. So the Woreda Health office and Health Extension Workers should consider empowering women, awareness and accessible antenatal care services, hygiene and sanitation to reduce acute malnutrition.

KEYWORDS: Acute-Malnutrition (wasting). 


\section{INTRODUCTION}

Malnutrition is lack of right kinds of food and nutrients needed by the body for appropriate growth and development. It includes under nutrition and over nutrition. Stunting, wasting, and underweight are classified as among Anthropometric indicators commonly used to measure malnutrition in a population of under five children(1).Acute Malnutrition is classified into severe acute malnutrition (SAM) and moderate acute malnutrition (MAM) according to the degree of wasting and the presence of oedema(2).

The Sustainable Development Goals (SDGs) states that by "2030 end preventable under-five deaths by reducing under 5 mortality to at least as low as 25 per 1,000 live births." However in 2015 about 480,000 under five children continue to die every month globally. A large percentage of these deaths were caused by preventable diseases. Moreover, under nutrition remains a major cause of disability and mortality, ranked as the top cause of global burden of disease. Besides it is underlying causes of deaths in $53 \%$ children under-five years. Of total under five deaths contributed by under nutrition, acute malnutrition is responsible for more than $28 \%$ (3) and around one million children under the age of five die every year from severe acute malnutrition(4).Globally, about 52 million under-five years old were wasted and among this around 32\%(16million) were severely wasted(5,6). And One-third of these children live in Africa Especially In Sub-Saharan Africa, Approximately $9 \%$ of children have moderate acute malnutrition and about $2 \%$ of children have Sever Acute Malnutrition(4)

In line with the above report; the 2016 Ethiopian Demographic and Health Survey (EDHS) revealed that there has been improvement in the nutritional status of children. The percentage of stunting slightly fell from $40 \%$ in 2014 to $38 \%$ in 2016.Similarly the percentage of underweight children declined from $25 \%$ to $24 \%$, but the prevalence of wasting is increased from $9 \%$ to $10 \%$. Furthermore the prevalence of wasting is different from region to region for instance In Oromia

regional state, the percentage of children who were wasted is $10.6 \%$ and in Somali regional state was $22.7 \%(7)$. 
The study conducted at Christ specialist Hospital, Ogui, Enuu, Nigeria and The two stage sampling procedure to collect cross-sectional survey at Kombolcha District of Eastern Harerghe zone, Oromia Regional state, Ethiopia shows that the prevalence of acute malnutrition (wasting) were $14.8 \%$ and $11.2 \%$ respectively $(8-10)$

There are multi-factorial causes of malnutrition among under five children according to Study conducted in Dara district of Sidama zone describes that wasting and underweight were extremely high among children of low land society. Altitude was the determinant factor for wasting and underweight and house hold income was major determinant of acute malnutrition(11).Nested case control study done in Eastern rural Ethiopia result shows acute under nutrition among the cohort of children, was associated with poor and middle households socio-economic positions, individually made decision strategy on the treatment/care of the sick child, paternal education(12)

In line with the above the study conducted at Gondar University hospital to identify the risk factors of acute malnutrition were the socioeconomic factors that were associated with severe acute malnutrition were maternal illiteracy, paternal illiteracy, monthly family income of less than 50 USD and large family size with the number of children greater than three(13).Matched case control study done in Shashogo woreda to determine risk factors of SAM socioeconomic factors that were associated with acute malnutrition were lack of maternal autonomy in decision making $(\mathrm{AOR}=4.13,95 \% \mathrm{CI}, 1.34-11.47)(14)$

Acute malnutrition is a problem of public health importance that disproportionately affects every region, including Ethiopia. Although Ethiopia is implementing different nutritional interventions but the prevalence of wasting is still increasing, and there is no scientific study done previously in the study area. the government in general and the District Health office need to have scientific bases on prevalence and possible determinants of wasting for which this study will supply valuable information. In additions, this study can help different stakeholders by paving the way to effective intervention in halting the morbidity and mortality associated with acute malnutrition.Therefore, improved understanding on prevalence and determinants of wasting locally helps the intervention to shoot the target and to design an effective strategy. 


\section{METHOD AND MATERIALS}

\section{Study setting, design, and period}

The study was carried out in Shashemene woreda which is found in West Arsi Zone of Oromia Regional state, study was conducted from July 1 to 30 2018. The district is located at $250 \mathrm{Km}$ far from Addis Ababa; the capital city of Ethiopia. Administratively the woreda is divided in to 38 rural administrative kebeles with 265,109 total populations with males to females ratio 1:1.02 living with 55,231 households and the under-five children are 43,557 projected from the 2007 national population census(15). The climatic condition of a woreda is $51.4 \%$ kola, $27 \%$ Weina Dega and $21.6 \%$ Dega. Its altitude ranges between 1,500 to 2,300 meters above sea-level. Regarding health infrastructures there are 8 health centers, 3private clinics and 38 health posts. Majority of populations were engaged in agricultural activities in the woreda and the main crops/products being Maize, Teff, and Sorghum, fruits and vegetables and animal husbandry.

\section{Source and Study population}

\section{Source Population}

All children under five years of age in the selected kebeles were source population.

\section{Study population}

Those children under-five years of age who lived in the selected Households were the study population.

\section{Eligibility criteria}

Those children below five years of age who lived in the selected households were included However Physically disabled and critically ill children who were in the age of below five years; since it is difficult to take anthropometric measurement were excluded from the study.

\section{Sample size determination and sampling procedures}

Sample size was determined using single population proportion formula. The sample size of the study was determined into the consideration of $95 \%$ confidence interval, $5 \%$ margine of error, and $23.6 \%$ prevalence of acute malnutrition from previous study done in Hawassa zuria district, Southern Ethiopia(16). After including $10 \%$ of non-response rate and since study group was 
stratified twice (multistage) the design effect was taken to be 1.5 finally 457individuals were included in the study.

For sampling procedures Initially, from the 38 kebeles in Shashemene woreda, 11 kebeles (30\%) were selected using simple random sampling (lottery method).Each kebeles were given code (0138) and these number were written on a small pieces of paper, all of them were put in a box, and then the box was shaken vigorously to ensure randomization, then 11-papers were taken out of the box and the numbers were recorded.

The total sample size was distributed to each kebeles proportionally to their population size. Then a random direction was employed from the center of the kebele to select the households with underfive children in the selected kebeles.

A maximum of one child aged younger than 5 years was included randomly in each selected households.

\section{Variables of the study}

Acute Malnutrition where the dependent variable whereas Socio demographic characteristics(Maternal/Parental education, Maternal/Parental occupation, family size), Child and health related characteristics(Sex, Age, immunization status, Morbidity status), Child caring practices /Nutritional care and practice(Exclusive breast feeding practice, Complimentary feeding practice, Duration of breast feeding ,Feeding of seek child),Maternal characteristics/Obstetric factors(Number of children ever born, Maternal autonomy in decision making, Health status during pregnancy ,Use of extra food during pregnancy or lactation ), Environmental Health condition( Access to Latrine, Access to save water, Access to Health Facilities).

\section{Operational Definitions}

Acute Malnutrition (Wasting): - a child's weight for height measurement is less than -2SD or bilateral pitting oedema.

Bilateral pitting oedema: bilateral pitting oedema also known as edematous malnutrition is assign of SAM. It is defined by bilateral pitting edema of the feet and verified when thumb pressure applied on top of both feet for three seconds leaves a pit (indentation) in the foot after the thumb 
is lifted. It is an abnormal infiltration and excess accumulation of serous fluid in connective tissue. This type of edema, beginning in the lower is most commonly nutritional in origin.

Critically ill: a child who has chronic disease like severe pneumonia, TB, CHF, DM and HIV/AIDS

Anthropometrics: Measurement of the human body E.g. weight and height.

Dietary diversity score: is the sum of total number of food groups consumed over 24 hours before the data collection

Health care seeking behavior: health care seeking behavior by the caregiver of the child within 24 hours of the onset of symptoms.

Immunization status: either vaccinated or not, If possible looking at vaccination card or asking the mother (caregiver).

Morbidly status of the child - morbidity status in the last 2 weeks before the study period (fever, cough, diarrhea)

Illiteracy: an able to read and write

Complementary foods: are foods which are required by the child, after six months of age, in addition to sustained breastfeeding

\section{Data collection tools and procedures}

For face to face interview were conducted using pre-tested and standardized questionnaire with questions adopted and modified from Different literature reviews, were used to collect data. Trained data collectors were assigned to all kebeles to collect the data from sample population. Informed verbal consent was obtained from all participants and the information from participants was kept confidential, Vaccination status of the children was assessed looking at vaccination card or asking the mother (caretaker).

Anthropometric data were collected through measurement of length/height and weight of all children. Salter hanging spring scale with graduations of $0.1 \mathrm{~kg}$ and a capacity for $25 \mathrm{~kg}$ were used for measuring the weight of the children aged 0-23 month and beam scale for children over 24 months of age were used for measuring weight with minimum clothing and no shoes to the nearest $0.1 \mathrm{~kg}$. Recumbent length measurement was taken for children under two years of age while for children above two years stature was measured in a standing position in centimeters to the nearest 
of $0.1 \mathrm{~cm}$ Oedema of the feet was diagnosed if a bilateral depression (pitting) remained after the pressure was released.

Child dietary diversity score were calculated by summing a total of 7 food groups [1) Grains, roots and tubers; 2) Vitamin A rich fruits and vegetables; 3) Dairy product; 4) Flesh foods (meat, fish, poultry and liver or organ meat); 5) Other fruits and vegetables; 6) Egg; 7) Legumes and nuts; consumed over reference period ( 24 hours before the data collection). For example, if one child eats from each food group, his/her DDS were 7

\section{Data quality assurance}

The questionnaire was translated into local languages, Afan Oromo, for the field work and back to English to check its consistency by three health workers who are fluent speakers Afan Oromo and English. Besides, it was pre-tested in Shalla Woreda in 5\% of the sample size. Twelve diploma nurses for data collection and Four BSc nurses for supervision were trained for Two days. The training was cover on the questionnaire, and the importance of disclosing the possible benefits and purpose of the study to the study participants before the starting data collection. The data collection was supervised by the principal investigator. Every questionnaire were supervised and reviewed for completeness and logical consistency. The completeness of the questionnaire was also checked before data entry. Validation of instruments, and measurements and random auditing were done on a daily basis. Double data entry would be used to ensure data quality.

\section{Data processing and analysis}

EPI info version 7software was used for data entry and cleaning and then the data were exported to SPSS Version 21 for further processing and analysis. World Health Organization (WHO) Anthro software were used to convert nutritional data indices from anthropometric measurement into Z-scores. Binary logistic regression model were used to compute the association between each independent variables and dependent variables. Independent variables that show association with outcome during bivariate analysis at $\mathrm{P}$ value less than 0.25 were included in multivariate analysis to control for potential confounders. Descriptive analysis were used to describe the percentages and number of distributions of the respondents by socio demographic characteristics and other relevant variables in the study.

Hosmer-Lemshow goodness-of-fit were used to test for the model fitness and forward step-wise (likelihood ratio) method were also conducted. Adjusted odds ratio (AOR) along with $95 \%$ 
confidence interval were estimated to assess the strength of the association and a $\mathrm{P}$ value $<0.05$ were considered to declare the statistical significance in the multivariable analysis in this study.

\section{RESULT}

\section{Characteristics of the study Participants}

A total of 457 under five children were participated in the study with a response rate of $100 \%$. As indicated in table1, 433(94.75\%) households were headed by males and 414(90.59\%) respondent were married. The mean age of the children and mothers were 25 months and 26.9 years respectively. Majority of the mothers/care takers 414(90.60\%) were Oromo and 366(80.09\%) of the respondents were Muslims in their religion.

Of the total $240(52.52 \%)$ of the care givers as well as $275(60.18)$ of the father were attend formal education.

Majority of the mothers $421(92.12 \%)$ were house wife with no occupation while the main paternal Occupation is farming.374 (81.84\%) of households were had farm lands out of them 16(4.17) were less than 1 hectare while 26(6.77\%) were more than 3 hectares and concerning decision making in the households, $240(52.52 \%)$ of the under five children mothers were autonomous in decision making.

Out of the respondents, $314(68.71 \%$ ) had average and less than five family size, while $143(31.29 \%)$ of households have more than five. 
Table 1 : Socio demographic Characteristics of study participants in Shashemene District, West Arsi Zone, Oromia Regional State, Ethiopia, July 2018

\begin{tabular}{|c|c|c|c|c|}
\hline \multirow{2}{*}{ S.No } & \multirow{2}{*}{ Variables } & \multirow{2}{*}{ Categories } & \multicolumn{2}{|c|}{ Total } \\
\hline & & & No & $\%$ \\
\hline \multirow[t]{2}{*}{1} & Head of the $\mathrm{HH}$ & Male & 433 & 94.75 \\
\hline & & Female & 24 & 5.25 \\
\hline \multirow[t]{3}{*}{2} & Ethnicity & Oromo & 414 & 90.60 \\
\hline & & Wolayita & 30 & 6.56 \\
\hline & & Others* & 13 & 2.84 \\
\hline \multirow[t]{4}{*}{3} & Religion & Muslim & 366 & 80.09 \\
\hline & & Protestant & 42 & 9.19 \\
\hline & & Orthodox & 32 & 7.00 \\
\hline & & Catholic & 17 & 3.72 \\
\hline \multirow[t]{2}{*}{4} & Land owner ship & Yes & 384 & 84.03 \\
\hline & & No & 73 & 15.97 \\
\hline \multirow[t]{2}{*}{5} & Maternal Illiteracy & Yes & 240 & 52.52 \\
\hline & & No & 217 & 47.48 \\
\hline \multirow[t]{2}{*}{6} & Paternal illiteracy & Yes & 275 & 60.18 \\
\hline & & No & 182 & 39.82 \\
\hline \multirow[t]{3}{*}{7} & Area of Agricultural Land & $<1$ hec & 16 & 4.17 \\
\hline & & 1-2hec & 342 & 89.06 \\
\hline & & $>3 h e c$ & 26 & 6.77 \\
\hline \multirow[t]{3}{*}{8} & Occupation of the mother & House wife & 421 & 92.12 \\
\hline & & Merchant & 27 & 5.91 \\
\hline & & Other** & 9 & 1.97 \\
\hline \multirow[t]{3}{*}{9} & Occupation of the Husband & Farmer & 374 & 81.84 \\
\hline & & Merchant & 60 & 13.13 \\
\hline & & Other** & 23 & 5.03 \\
\hline \multirow[t]{2}{*}{10} & Family size & $<=5$ & 314 & 68.71 \\
\hline & & $>5$ & 143 & 31.29 \\
\hline \multirow[t]{2}{*}{11} & Maternal Autonomy & Yes & 240 & 52.52 \\
\hline & & No & 217 & 47.48 \\
\hline \multirow[t]{3}{*}{12} & Marital status & Married & 414 & 90.59 \\
\hline & & Divorced & 26 & 5.69 \\
\hline & & Other*** & 17 & 3.72 \\
\hline
\end{tabular}

*Amhara, Wolayita, Sidama;**employee, daily Laborer;***Widowed, Separated, Single 


\section{Maternal and Child Characteristics}

A total of 457 under five children were screened for acute malnutrition, from the total 213(46.61\%) were males and 244(53.39\%) were females. Among the total children aged 0-59 months, 21(4.6\%), $203(44.42 \%), 233(50.98 \%)$, found on the age group of 0-5, 6-23 and 24-59 months respectively. The mean age of the children was 25 months with SD of \pm 15.72 .

From the total children,206(45.08\%) were delivered at home and 251(54.92\%) children were delivered at health facilities and 24(5.25\%),231(50.55\%) and 202(44.20\%) of children were born less than nine months, at nine months and greater than nine months respectively. Out of these $17(3.72 \%)$ of the children were twin.

Concerning vaccination status and vitamin A supplementation, 432(94.53\%) of children were vaccinated and 181(41.51\%) of children were supplemented with vitamin A respectively. However, only $25(5.47 \%)$ children were not immunized.

Among the surveyed 457 mothers 432(94.53\%) of mothers/care givers of children were in the age group less than 35 years and Antenatal follow up were practiced in 395(86.43\%) of the mothers while $135(29.54 \%)$ and $118(25.82 \%)$ mothers were did not take extra meal during pregnancy and Lactation respectively. 
Table 2 : Maternal and Child Characteristics of study participants in Shashemene District, West Arsi Zone, Oromia Regional State, Ethiopia, July 2018

\begin{tabular}{|c|c|c|c|c|}
\hline \multirow{2}{*}{ S.No } & \multirow{2}{*}{ Variables } & \multirow{2}{*}{ Categories } & \multicolumn{2}{|c|}{ Total } \\
\hline & & & No & $\%$ \\
\hline \multirow[b]{2}{*}{1} & \multirow{2}{*}{$\begin{array}{l}\text { Age of the mothers/care givers } \\
\text { (Years) }\end{array}$} & $<35$ & 432 & 94.53 \\
\hline & & $>=35$ & 25 & 5.47 \\
\hline \multirow{3}{*}{2} & \multirow{3}{*}{$\begin{array}{l}\text { Maternal extra meal during the } \\
\text { last pregnancy }\end{array}$} & 0 & 135 & 29.54 \\
\hline & & 1 & 234 & 51.20 \\
\hline & & 2 & 88 & 19.26 \\
\hline \multirow{3}{*}{3} & \multirow{3}{*}{$\begin{array}{l}\text { Maternal extra meal during the } \\
\text { last lactating }\end{array}$} & 0 & 118 & 25.82 \\
\hline & & 1 & 242 & 52.95 \\
\hline & & 2 & 97 & 21.23 \\
\hline \multirow{2}{*}{4} & \multirow{2}{*}{ ANC visit } & Yes & 395 & 86.43 \\
\hline & & No & 62 & 13.57 \\
\hline \multirow{2}{*}{5} & \multirow{2}{*}{ age of the mothers at first birth } & $<=20$ & 384 & 84.03 \\
\hline & & $>20$ & 73 & 15.97 \\
\hline \multirow{3}{*}{6} & \multirow{3}{*}{$\begin{array}{l}\text { Distance from the } \mathrm{HH} \text { to the } \mathrm{HF} \\
\text { (Minutes) }\end{array}$} & $<30$ & 317 & 69.37 \\
\hline & & $>=30$ & 140 & 30.63 \\
\hline & & $0-5$ & 21 & 4.60 \\
\hline \multirow[t]{2}{*}{7} & \multirow[t]{2}{*}{ Age of the child (Months) } & $6-23$ & 203 & 44.42 \\
\hline & & $24-59$ & 233 & 50.98 \\
\hline \multirow{2}{*}{8} & \multirow{2}{*}{ Sex of the child } & Male & 213 & 46.61 \\
\hline & & Female & 244 & 53.39 \\
\hline \multirow{2}{*}{9} & \multirow{2}{*}{ Child received Deworming } & Yes & 98 & 43.95 \\
\hline & & No & 125 & 56.05 \\
\hline \multirow{2}{*}{10} & \multirow{2}{*}{ Child received Vitamin A } & Yes & 181 & 41.51 \\
\hline & & No & 255 & 58.49 \\
\hline \multirow{2}{*}{11} & \multirow{2}{*}{ Type of Birth } & Single & 440 & 96.28 \\
\hline & & Multiple/Twins & 17 & 3.72 \\
\hline \multirow{2}{*}{12} & \multirow{2}{*}{ Child Vaccination status } & Yes & 432 & 94.53 \\
\hline & & No & 25 & 5.47 \\
\hline \multirow{2}{*}{13} & & Home & 206 & 45.08 \\
\hline & Place of Birth & $\mathrm{HI}$ & 251 & 54.92 \\
\hline & History of Diarrhea in the last & Yes & 111 & 24.29 \\
\hline 14 & two weeks & No & 346 & 75.71 \\
\hline & History of febrile illness in the & Yes & 28 & 6.13 \\
\hline 15 & last two weeks & No & 429 & 93.87 \\
\hline
\end{tabular}




\section{Child Caring Practice}

All of the children's mothers have been breast feed their child. Among these 320(70.02\%) of children had breast feeding that was initiated within one hour after birth and 90(19.69\%) of children took pre Lacteal feeding.

From the total children 281(61.49\%) of children's mother were exclusively breast feed their child for the first six months.

About 323(74.08\%) of the children started complementary feeding in addition to breast feeding at the age of 6 months while $111(25.46 \%)$ of the children were started complementary feeding in addition to breast feeding at the age less than six months.

Regarding method s of feeding majority of the children who were started complementary feeding 240(55.04\%) were used by spoon while 147(33.72\%) and 49(11.24\%) were used by bottle and cup respectively. among these $315(72.25 \%)$ of children were consumed diversified food groups less than 4 within 24 hours while 121(27.75\%) of children were consumed diversified food groups greater than or equal to 4 within 24 hours. 
Table 3 : Child Caring Practices of the study population in Shashemene District, West Arsi Zone, Oromia Regional State, Ethiopia, July 2018

\begin{tabular}{|c|c|c|c|c|}
\hline \multirow[t]{2}{*}{ S.No } & \multirow[t]{2}{*}{ Variables } & \multirow[t]{2}{*}{ Categories } & \multicolumn{2}{|c|}{ Total } \\
\hline & & & No & $\%$ \\
\hline \multirow[t]{4}{*}{1} & \multirow{4}{*}{$\begin{array}{l}\text { For how Long have you breast } \\
\text { fed your child }\end{array}$} & $<6$ month & 19 & 4.16 \\
\hline & & up to 12 month & 54 & 11.81 \\
\hline & & for 24 month & 296 & 64.77 \\
\hline & & more than 24 month & 88 & 19.26 \\
\hline \multirow[t]{2}{*}{2} & \multirow[t]{2}{*}{ DDS } & $<4$ & 315 & 72.25 \\
\hline & & $>=4$ & 121 & 27.75 \\
\hline \multirow[t]{2}{*}{3} & \multirow[t]{2}{*}{ Time of breast feed initiation } & within the first hour & 320 & 70.02 \\
\hline & & $\begin{array}{l}\text { after the first hour of } \\
\text { delivery }\end{array}$ & 137 & 29.98 \\
\hline \multirow[t]{2}{*}{4} & \multirow[t]{2}{*}{ Child Deprive colostrum's } & Yes & 81 & 17.72 \\
\hline & & No & 376 & 82.28 \\
\hline \multirow[t]{2}{*}{5} & \multirow{2}{*}{$\begin{array}{l}\text { EBF of the Child during the } \\
\text { first six month }\end{array}$} & Yes & 281 & 61.49 \\
\hline & & No & 176 & 38.51 \\
\hline \multirow[t]{3}{*}{6} & Age of the child while starting & $<6$ month & 111 & 25.46 \\
\hline & \multirow[t]{2}{*}{$\mathrm{CF}$} & at 6month & 323 & 74.08 \\
\hline & & 6-12 months & 2 & 0.46 \\
\hline \multirow[t]{3}{*}{7} & \multirow[t]{3}{*}{ Method of feeding } & Bottle & 147 & 33.72 \\
\hline & & Cup & 49 & 11.24 \\
\hline & & Spoon & 240 & 55.04 \\
\hline \multirow[t]{2}{*}{8} & \multirow[t]{2}{*}{ Pre Lacteal feeding } & Yes & 90 & 19.69 \\
\hline & & No & 367 & 80.21 \\
\hline \multirow[t]{2}{*}{9} & \multirow[t]{2}{*}{ Frequency of breast feeding } & $4-7$. & 155 & 33.92 \\
\hline & & $>=8$ & 302 & 66.08 \\
\hline \multirow[t]{2}{*}{10} & \multirow{2}{*}{$\begin{array}{l}\text { Change Pattern of feeding for } \\
\text { sick child }\end{array}$} & Yes & 222 & 48.58 \\
\hline & & No & 235 & 51.42 \\
\hline
\end{tabular}




\section{Environmental Factors}

From the surveyed households $399(87.30 \%$ ) households were got water from piped outside the compound. The average water utilized per households were 35 Liters per day. And the average round trip to fetch water from the source of water were 37.24 minutes.

Concerning household domestic Liquid and solid waste disposal 274(59.96\%) and 234(51.20\%)

of the households were dispose domestic liquid and solid waste at open field respectively and Latrine were not available in $75(16.4 \%)$ of households

Regarding the residence house 269(58.9\%) of households had hatched home while 188(41.1\%) were corrugated iron sheet. About $317(69.41 \%)$ of the households had separate room for kitchen. 
Table 4: Environmental Characteristics of the study population in Shashemene District, West Arsi Zone, Oromia Regional State, Ethiopia, July 2018

\begin{tabular}{|c|c|c|c|c|}
\hline \multirow{2}{*}{ S.No } & \multirow{2}{*}{ Variables } & \multirow{2}{*}{ Categories } & \multicolumn{2}{|c|}{ Total } \\
\hline & & & No & $\%$ \\
\hline \multirow{2}{*}{1} & \multirow{2}{*}{ Latrine Availability } & Yes & 382 & 83.59 \\
\hline & & No & 75 & 16.41 \\
\hline \multirow{2}{*}{2} & \multirow{2}{*}{$\begin{array}{l}\text { Domestic Liquid waste } \\
\text { disposal }\end{array}$} & Open field & 274 & 59.96 \\
\hline & & Pit & 183 & 40.04 \\
\hline \multirow{4}{*}{3} & \multirow{4}{*}{$\begin{array}{l}\text { HH domestic solid waste } \\
\text { disposal }\end{array}$} & Open field & 234 & 51.20 \\
\hline & & Pit & 133 & 29.10 \\
\hline & & Burning & 10 & 2.20 \\
\hline & & Composting & 80 & 17.50 \\
\hline \multirow{2}{*}{4} & \multirow{2}{*}{ Type of residence house } & Thatched & 269 & 58.86 \\
\hline & & Corrugated Iron sheet & 188 & 41.14 \\
\hline \multirow{2}{*}{5} & \multirow{2}{*}{ Kitchen site } & Inside residential house & 140 & 30.63 \\
\hline & & Separated & 317 & 69.37 \\
\hline \multirow{2}{*}{6} & \multirow{2}{*}{ Live together with animals } & Yes & 127 & 27.80 \\
\hline & & No & 330 & 72.20 \\
\hline \multirow{4}{*}{7} & \multirow{4}{*}{ Source of Drinking water } & $\begin{array}{l}\text { Piped outside the } \\
\text { compound }\end{array}$ & 399 & 87.30 \\
\hline & & Covered well & 21 & 4.60 \\
\hline & & Protected spring & 35 & 7.66 \\
\hline & & Open well & 2 & 0.44 \\
\hline \multirow{2}{*}{8} & \multirow{2}{*}{$\begin{array}{l}\text { Take to HI when the child is } \\
\text { sick }\end{array}$} & within 24 hours & 235 & 51.42 \\
\hline & & More than 24 hours & 222 & 48.58 \\
\hline
\end{tabular}




\section{Prevalence of wasting}

A total of 91(19.91\%) of screened under-five children were wasted. Among the total wasted underfive children 3(14.29\%),26(26.53\%),30(28.57\%),18(25.71\%),6(7.41\%) and 8(9.76\%) found on the age group of 0-5,6-11,12-23,24-35,36-47 and 48-59 months respectively.

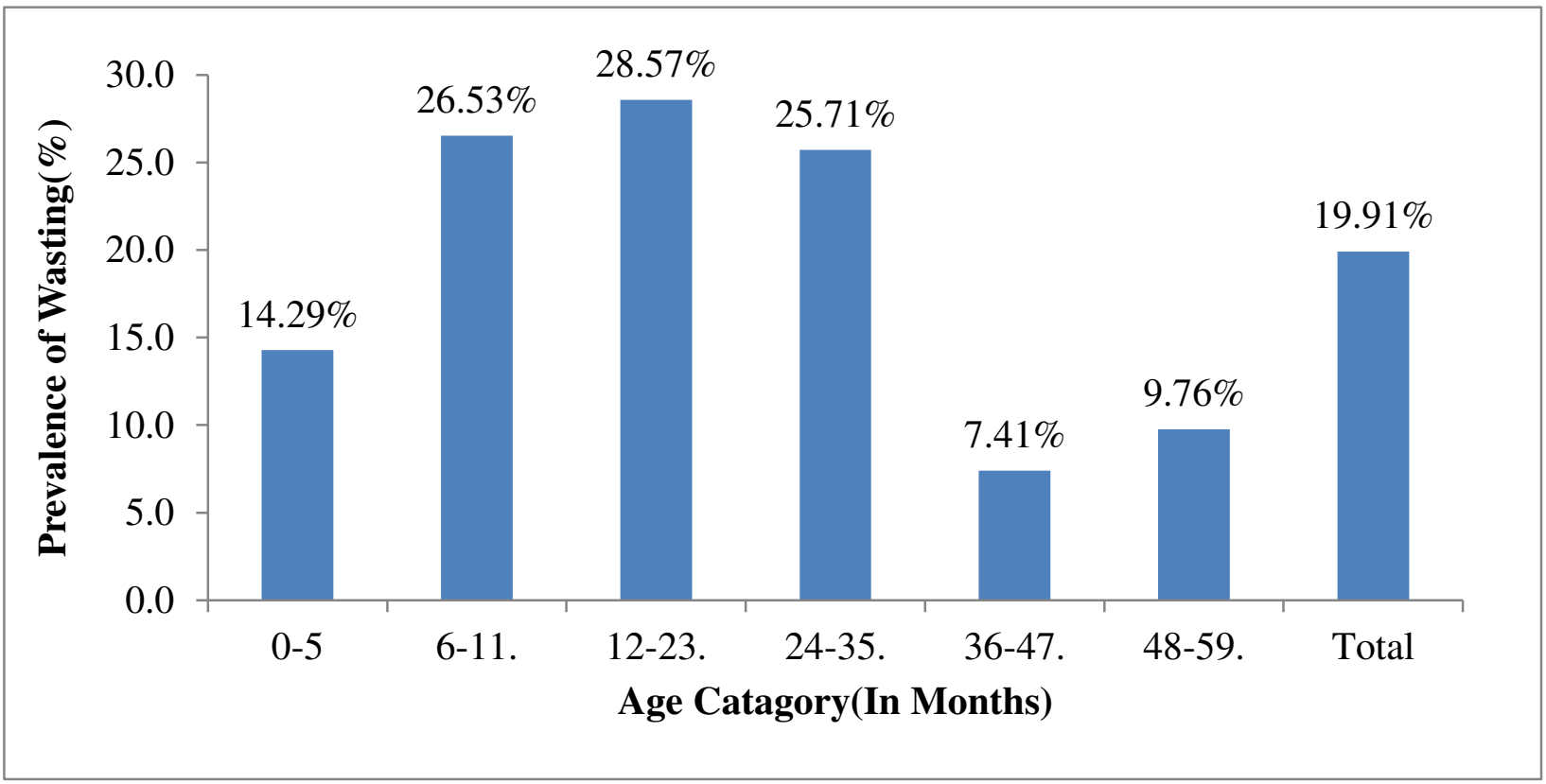

Figure 1: Prevalence of wasting by age among children aged 0-59 months in Shashemene District, West Arsi Zone, Oromia Regional State, Ethiopia, July 2018. 


\section{Factors associated with acute malnutrition (Wasting)}

In Bivariate Analysis, Parental education, Maternal autonomy in decision making, Squeezed out and throw colostrum, ANC visit, History of Diarrhea in the last two weeks, History of febrile disease in the last two weeks, Age of Mather at first birth, place of birth, Maternal education and pre Lacteal feeding were the variables that showed an association with the outcome variable at the bivariate analysis with $\mathrm{P}$ value $<0.25$ were entered into the final multivariable logistic regression to control potential confounders.

Then after using standard multiple logistic regression to assess the impacts of candidate variable on acute malnutrition four independent variables namely, Mothers who had no power in decision making, squeezed out and throw colostrum's, Mothers who had no ANC visit, child's history of Diarrhea in the last two weeks were independent determinants of acute malnutrition.

Maternal ANC visit were significant determinant for Acute malnutrition, children whose mother were not on ANC visit were 2 times more likely to be Acute malnourished than those children whose mothers were on ANC visits(AOR=2.26,95\%CI 1.14-4.46). The odds of developing wasting was 2 times higher among children whose mother has not autonomous in decision making than those whose mother has autonomous in decision making(AOR=2.42,95\% CI 1.42-4.12).

Morbidity status of the child by diarrheal disease in the last 2 weeks preceding the survey were also seen one of the determinant of the acute malnutrition in under five children. Acute malnutrition was 2 times less likely to occur in children who had no diarrhea before 2 weeks than those children who had diarrhea within two weeks ( $\mathrm{AOR}=2.07,95 \% \mathrm{CI}$ 1.19-3.59). Although children who had fever in the last two weeks preceding the survey shows significant association in bi variable analysis, no association was observed between children who had fever in the last two weeks preceding the survey and wasting in multivariable analysis.

Similarly children whose mothers had squeeze out of colostrums were 2 times more likely to be wasted than under five children whose mothers had no squeeze out colostrums(AOR=1.99,95\% CI 1.07-3.71). 
Table 5 Factors associated with wasting among children under five years, of Shashemene

District, West Arsi Zone, Oromia Regional State, Ethiopia, July 2018 July 2018

\begin{tabular}{|c|c|c|c|c|c|c|}
\hline \multirow[t]{2}{*}{ S.No } & \multirow[b]{2}{*}{ Variable } & \multicolumn{2}{|c|}{ Wasting } & \multirow[t]{2}{*}{ COR $(95 \%$, CI $)$} & \multirow[t]{2}{*}{$\operatorname{AOR}(95 \%, C I)$} & \multirow[t]{2}{*}{ P-Value } \\
\hline & & Yes & No & & & \\
\hline \multirow[t]{3}{*}{1} & Paternal illiteracy & & & & & \\
\hline & Yes & 48 & 134 & 1 & & \\
\hline & No & 43 & 232 & $1.93(1.19-3.03)$ & & \\
\hline \multirow[t]{3}{*}{2} & Maternal Autonomy & & & & & \\
\hline & Yes & 39 & 201 & 1 & 1 & \\
\hline & No & 52 & 165 & $1.62(1.02-2.58)$ & $2.42(1.42-4.12)$ & 0.001 \\
\hline \multirow[t]{3}{*}{3} & ANC visit & & & & & \\
\hline & Yes & 71 & 324 & 1 & 1 & \\
\hline & No & 20 & 42 & $2.17(1.20-33.92)$ & $2.26(1.14-4.46)$ & 0.019 \\
\hline \multirow[t]{3}{*}{4} & $\begin{array}{l}\text { History of Diarrhea in the last } \\
\text { two weeks }\end{array}$ & & & & & \\
\hline & Yes & 30 & 81 & $1.73(1.05-2.56)$ & $2.07(1.19-3.59)$ & 0.010 \\
\hline & No & 61 & 285 & 1 & 1 & \\
\hline \multirow[t]{3}{*}{5} & $\begin{array}{c}\text { History of febrile illness in the } \\
\text { last two weeks }\end{array}$ & & & & & \\
\hline & Yes & 10 & 18 & $2.39(1.06-5.37)$ & & \\
\hline & No & 81 & 348 & 1 & & \\
\hline \multirow[t]{3}{*}{6} & Child Deprive colostrums & & & & & \\
\hline & Yes & 28 & 53 & $2.62(1.54-4.47)$ & $1.99(1.07-3.71)$ & 0.029 \\
\hline & No & 63 & 313 & 1 & 1 & \\
\hline \multirow[t]{3}{*}{7} & Age of the mother at first birth & & & & & \\
\hline & $<=20$ & 68 & 316 & $2.14(1.22-3.74)$ & & \\
\hline & $>20$ & 23 & 50 & 1 & & \\
\hline \multirow[t]{3}{*}{8} & Place of birth & & & & & \\
\hline & Home & 50 & 156 & $1.64(1.03-2.61)$ & & \\
\hline & $\mathrm{HI}$ & 41 & 210 & 1 & & \\
\hline \multirow[t]{3}{*}{9} & Maternal Illiteracy & & & & & \\
\hline & Yes & 37 & 203 & 1 & & \\
\hline & No & 54 & 163 & $1.82(1.14-2.89)$ & & \\
\hline \multirow[t]{3}{*}{10} & Pre Lacteal feeding & & & & & \\
\hline & Yes & 31 & 59 & $2.69(1.61-4.50)$ & & \\
\hline & No & 60 & 307 & 1 & & \\
\hline \multirow[t]{4}{*}{11} & $\begin{array}{l}\text { Maternal extra meal during } \\
\text { Lactating }\end{array}$ & & & & & \\
\hline & 0 & 27 & 91 & $2.90(1.29-6.52)$ & & \\
\hline & 1 & 55 & 187 & $2.88(1.36-6.08)$ & & \\
\hline & 2 & 9 & 88 & 1 & & \\
\hline
\end{tabular}




\section{DISCUSSION}

In this study, the prevalence of wasting is $19.91 \%$ at $95 \% \mathrm{CI}$ and Maternal autonomy in decision making, squeezed out and throw colostrums, ANC visit, History of Diarrhea in the last two weeks, shows significant association with wasting.

This study showed that prevalence of wasting is $19.91 \%$ at $95 \%$ CI.The result of this study revealed that, the prevalence of wasting were higher as compared with a community cross sectional study conducted in Bule Hora District, South Ethiopia, Hidabu Abote, North shewa, Oromia regional state and Damot Gale, South Ethiopia $(13.4 \% 16.7 \%, 9 \%),(17,18)$. This difference might be due to study period, study area, sample size and the inclusion of children under the age of six months. In this study, data were collected in July when most rural areas have shortage of food; this could probably one of the reasons for high prevalence of wasting in the area. Although present study result showed that the prevalence of wasting were high in the district in comparison with the regional and national prevalence reported by EDHS $2016(10.6 \%, 11 \%)(15)$. The discrepancy might be due to sample size compared to that of national data and although it signifies acute malnutrition problem is probably due to illness like diarrheal morbidity and due to most of the time the district were affected by drought.

Even though the prevalence of wasting were high in this district but nearly similar with the study conducted in Hawassa Zuria District, Southern Ethiopia (23.6\%)(16). This similarity may be due to socioeconomic, study design and sample size.

But the prevalence of acute malnutrition is low in this district when compared to a community based cross-sectional study conducted in 2012, the magnitude and factors associated with malnutrition in children 6-59 months of age in a pastoral community of Dolo Ado district, Somali region, Ethiopia shows that the prevalence of acute malnutrition (wasting) was $42.3 \%$ (17). This is may be due to Dolo Ado District were affected by drought and the community were pastoralist.

Similarly, the prevalence of wasting is low when compared to the study conducted at Christ specialist Hospital, Ogui, Enuu, Nigeria, about 25\% of children were wasted However the prevalence were low when compared to the study conducted in University of Nairobi shows that 
the prevalence of Wasting were $14.8 \%(9,10)$. This difference was might be due to the study design, socio demographic characteristics and exclusion of under-six months of children.

Maternal ANC visit were significant determinant for Acute malnutrition, children whose mother had no ANC visit were 2 times more likely to be Acute malnourished than those children whose mother has ANC visits, which is consistent with a community based cross sectional studies conducted on the prevalence of malnutrition and associated factors in children aged 6-59 months among rural dwellers of Damot Gale district, south Ethiopia shows children whose mothers attended $\mathrm{ANC}(\mathrm{AOR}=0.18,95 \% \mathrm{CI}, 0.07-0.45)$ were less likely for acute malnutrition and the studies conducted in Shone District, Hadiya Zone, SNNPR(AOR=0.51,95\%CI, 0.27-0.96) showed that children whose mother have antenatal care follow up is less with acute malnutrition of the children(19). Since the overall aim of antenatal care is to produce a healthy mother and baby at the end of pregnancy, taking antenatal visits may help the mother and child to have better health and knowledge of child caring practice.

Autonomy of mothers in decision making were significantly associated with wasting of under- five children. Children whose mothers were not autonomous in decision making were two times more likely wasted than those children whose mothers were autonomous in decision making. This result were consistent with studies conducted in Shashogo Woreda, Southern Ethiopia(AOR=4.13,95\%CI;1.34-11.47), and Machakel Woreda, Northwest Ethiopia $(\mathrm{AOR}=5.68,95 \% \mathrm{CI} ; 2.09-15.43)(13,14)$.Such decision might also require women's autonomy to participate in decision making process of the household equally with their husband. Now adays the policy of government also supports the empowering women, women education and increasing influentially of women has significant impact for the health of the family and community.

Recurrent infection has been associated with malnutrition, especially the child with diarrhea preceding 2 weeks before the onset of acute malnutrition is significantly associated with wasting of the children. This can be due excessive loss of fluids and electrolytes, loss of appetite, lack of absorption of food in the intestine due to high motility of the intestine during diarrhea episodes. Similar finding was seen in the studies done in Shashogo(AOR=4.13,95\%CI,1.34-11.47), Machakel $(\mathrm{AOR}=3.96 ; 95 \% \mathrm{CI}, 1.75-71.82$ and Damot Gale $(\mathrm{AOR}=3.95,95 \% \mathrm{CI}, 13.68-114.30)(13$, 14). On the other hand, the present study does not show significant association between morbidity status of the child with fever and acute malnutrition. This is inconsistent with the similar studies 
conducted in Gondar university and Oromia public hospitals(12, 20). This might be due to the district is a known malarious area and the homogeneousness of febrile disease of cases.

In the current study, there is no significant difference in children who have not exclusive breastfeeding and those children who have exclusive breast feeding. This is inconsistent with the other studies conducted in East rural Ethiopia and Oromia public hospitals(20, 21). This might be due to increased good awareness in breast feeding currently from the community. Exclusive breastfeeding is recommended because breast milk is containing necessary nutrients in the first few months of life. In addition, the mother's antibodies in breast milk provide the infant with immunity to disease. Early supplementation exposes infants to pathogens and thus increases their risk of infection, especially diarrheal disease and it decreases infants' intake of breast milk and therefore suckling, which in turn reduces breast milk production(22).

Squeeze out of first milk was significantly associated with acute malnutrition of under-five children. Children deprive colostrums was 2 times more likely wasted than those children who were no deprive colostrums. This result was consistent with a case control study conducted in machakel woreda(AOR=2.02;95\%CI,1.07-6.69) revealed that squeeze out of first milk was showed significant association with malnutrition(13).

A community based case-control study conducted on Determinants of acute malnutrition among children under-five years of age in Nepal shows that Low socio economic status(AOR=17.13,95CI,5.85-50.13), mothers age at birth, $<20$ or $>35$ years $(\mathrm{AOR}=3.21,95 \% \mathrm{CI}, 1.30-7.94), \quad$ Illiterate father(AOR=3.65,95\%CI,1.62-8.20), bottle feeding(AOR=2.19,95\%CL,1.73-12.03) and not initiated complementary feeding at the age of six month(AOR=2.91,95\%CI,1.73-12.03)were associated with acute malnutrition but this study is not. These might be due to study design, socio economic characteristics, and exclusion of under-six months of children, study period and sample size (10). 


\section{CONCLUSION AND RECOMMENDATION}

According to this study, the prevalence rate of wasting among under-five children in the district were high. children's whose mother had no ANC visit, no autonomy in decision making, squeezed out and throw colostrums and children who had diarrheal disease in the last two weeks were more likely to develop wasting.

The Woreda health office should create awareness and accessible antenatal care services through community health workers and women's developmental army to improve child care practice. The Woreda Health Office should focus on the intervention targeting the community for promotion of hygiene and sanitation as well as designing an intervention which increases mother's awareness related to causes of diarrheal disease and how to manage their children to make nutritional interventions more effective. The Health Extension Workers should strength pregnant and Lactating women's conference to make nutritional interventions more effective. Woreda administrative office and Woreda Health Office should encourage anyone who interested interventional work on women empowerment to participate in decision making through strengthening girls and women's participation in decision making.

\section{Limitation}

The findings may be prone to recall bias during data collection time as some of the variables need a recall to situations happened before the actual data collection time (example DDS, frequency of breast feeding, complementary feeding)

\section{List of Abbreviations}

ANC: Antenatal care; Arsi U: Arsi University; CF: Complementary Feeding; DDS: Dietary Diversity Score; EDHSE: Ethiopian Demographic and Health Survey; EBF: Exclusive Breast Feeding; EFY: Ethiopian Fiscal year; ETB: Ethiopian Birr; HH: Households; HI: Health Institution; MAM: Moderate Acute Malnutrition ; MUAC: mid Upper Arm Circumference ; SAM: Severe Acute Malnutrition; SD: Standard deviation; SDGs: Sustainable Development Goals; SSA: Sub Saharan Africa; UN: United Nations; WHO: World Health Organization; W/H: Weight/Height 


\section{Declarations}

\section{Ethics approval and consent to participate}

Ethical clearance were obtained from the Institutional Review Board at the College Health Sciences of Arsi University. In addition, Permission letter was obtained from the Shashemene district Health office before field activities started and verbal consents were obtained from the parents/caretakers of the study subjects after explaining the study objective and procedures.

\section{Funding}

The study was not funded by any organizations.

\section{Availability of data and materials}

The datasets created and analyzed during the study will be made available to organizations and individuals by the first author based on fair request.

\section{Authors' Contribution}

AI, TK, AF, DD and NS wrote the protocol, participated in data collection, analyzed the data and wrote the manuscript. All authors read and approved the final manuscript.

\section{Consent for publication}

Not applicable

\section{Competing interests}

The authors declare that they have no competing interests.

\section{ACKNOWLEDGMENT}

I would like to thank Arsi University, Department of Public Health, and college of Health Science for giving me this chance.

My thanks also go to Shashemene district Health Office for giving me pertinent information.

Finally I would like to extend my deep heartfelt gratitude for the data collectors, supervisors and children's mothers who participated in the study. 


\section{REFERENCE}

1. World Food Progremme, Nutrition at the World Food Programme. Programming for Nutrition Specific Intervention.; 2012.

2. FMoH. Protocol for the management of severe acute malnutrition guideline 2007. Addis Abeba,Ethiopia: Federal Ministry of Health; 2007.

3. UNICEF. Humanitarian action update: Horn of Africa crisis. New York: UNICEF;. 8 July 2011[cited 2012 December 30].

4. UNICEF. Humanitarian action update:Horn of Africa Cricis. New york: UNICEF; 8 July 2011.

5. UNICEF. Improving Child Nutrition:The achievable imperative for global progress. 2016

6. UNICEF. Improving Child Nutrition:The achievable imperative for global progress. 2013.

7. Ethiopian Central statistical Agency. Ethiopian Demographic and Health Survey. ICF International Calverton: Maryland. 2016.

8. Tadiwos Zewdie DA. Determinants of Child Malnutrition: Empirical Evidence from Kombolcha District of Eastern Hararghe Zone, Ethiopia. Quarterly Journal of International Agriculture. 3013;4.

9. Okwy-Nweke Chizoba, Maduforo Aloysius, Otiora C., C. U. Prevalence of severe acute malnutrition in childrenaged 6 -60 months admitted at mother of Christ specialist hospital Ogui, Enugu, Nigeria. European Journal of Preventive Medicine. 2014;2(4):45-51.

10. Leah N. Mututho, Willy K. Kiboi, Patrick K. Mucheru. Factors associated with exclusive breastfeeding in Kenya: a systematic review. International Journal of Community Medicine and Public Health. 2017;4(12):4358-62.

11. Nebiyu Melaku. Agro Ecological Comparison Of Levels And Correlates Of Nutritional Status Of Under Five Children In Dara Woreda Of Sidama Zone, Snnprs, Ethiopia 2007.

12. Solomon Demissie, Amare Worku. Magnitude and factors associated with malnutrition in children 6-59 months of age in pastoral community of Dollo Ado district, Somali region, Ethiopia. Science Journal of Public Health. 2013;1(4):175-83.

13. Bantamen G, Belaynew W, and Dube J. Assessment of Factors Associated with Malnutrition among Under Five Years Age Children at Machakel Woreda, Northwest Ethiopia: A Case Control Study. Nutrition \& Food Sciences. 2014;4(1).

14. Nebiyu Dereje. Determinants of Severe Acute Malnutrition among Under Five Children in Shashogo Woreda, Southern Ethiopia: A Community Based Matched Case Control Study. Journal of Nutrition \& Food Sciences. 2014;4(5).

15. Central Statistical Authority. 2007 Population And Housing Census Of Ethiopia. Addis Abeba,Ethiopia; 2007.

16. Dereje Danbe Debeko, Ayele Taye Goshu. Nutritional Status of Under- five Children in Hawassa Zuria District, Southern Ethiopia. American Journal of Health Research. 2015;3(5):286-92.

17. Mandefro Asfaw, Mekitie Wondaferash, Mohammed Taha, and Lamessa Dube. Prevalence of undernutrition and associated factors among children aged between six to fifty nine months in Bule Hora district, South Ethiopia. BMC Public Health. 2015;15(41).

18. Kebede Mengistu, Kassahun Alemu, Bikes Destaw. Prevalence of Malnutrition and Associated Factors Among Children Aged 6-59 Months at Hidabu Abote District, North Shewa, Oromia Regional State. Nutritional Disorders \& Therapy. 2013.

19. Endashaw Shibru. Determinants of nutrition security in shone district,hadiya zone,snnpr.Addis ababa university. 2009. 
20. Bokore A. Determinant of Acute malnutrition among children aged 6-59 months in public hospitals,oromia region,west Ethiopia. BMC Nutrition. 2015;1(34).

21. Egata G, Berhane Y, Worku A. Predictors of Acute undernutrition amon children aged 6 to 36 months in east rural Ethiopia: a community based nested case control study. BMC Pediatr. 2014;14(91). 22. WHO, UNICEF, The World Bank. Levels \& Trends in Child Malnutrition. Washington DC: UNICEF,WHO-World bank; 2012.

23. UNICEF. Anthropometric criteria for defining severe and moderate acute malnutrition. Nutrition HEAT Module. 2008.

24. WHO. Community-based management of severe acute malnutrition. nutrition publications. 2013.

25. Nilesh Kumar Pravana, Suneel Piryani. Determinants of severe acute malnutrition among children under 5 years of age in Nepal: a communitybased case-control study. BMJ Open. 2017.

26. Robert E Black, Lindsay H Allen, Zulfiqar A Bhutta, Laura E Caulfield. Maternal and child undernutrition: global and regional exposures and health consequences. Series. 2008.

27. Ismail D. Legason RD. Prevalence of acute malnutrition among children ages 6-59 months: Results from a baseline nutrition survey in North-Western Uganda. J Nutr Hum Health. 2018;2(1).

28. Lamirot Abera, Tariku Dejene, and Tariku Laelago. Prevalence of malnutrition and associated factors in children aged 6-59 months among rural dwellers of damot gale district, south Ethiopia: community based cross sectional study. International Journal for Equity in Health. 2017;16(111).

29. Neima Endris, Henok Asefa, and Lamessa Dube. Prevalence of Malnutrition and Associated Factors among Children in Rural Ethiopia. BioMed Research International. 2017;2017(6587853).

30. Abenet F, Simachew K, Gobu L. Child Malnutrition and Associated Factors among Drought Affected Pastoralists in the Somali Region, Eastern Ethiopia. Journal of Nutrition and Health Sciences. 2016;3(4).

31. Alemu Adeba DSG, Habtamu Fekadu,Wondu Garoma,. Prevalence of Wasting and Its Associated Factors ofChildren among 6-59 Months Age in Guto Gida District, Oromia Regional state, Ethiopia. Food Science and Quality Management 2014;24.

32. Desalegne Amare AN, Baye Tsegaye,Birtukan Assefa,and Birehanu Ayenie. Prevalence of Undernutrition and Its Associated Factors among Children below Five Years of Age in Bure Town, West Gojjam Zone, Amhara National Regional State, Northwest Ethiopia. Advances in Public Health. 2016.

33. Owor M, tumwinejk, kikafundajak. Socio-economic risk factors for severe protein energy malnutrition among children in mulago hospital,kampala. East Afr Med J. 2000;77(9):471-5.

34. Kirtisudhamisha, praveenkumar, srikantabasu. Risk factors for Severe acute malnutritionin chldren below 5 year of age in India: A case control study. India J pediatrics. 2013;81(8):762-5.

35. Alemayehu Eshetu. Determinants of severe acute malnutrition among children aged 6-59 months in konso , southern Ethiopia. Quality in Primary Care. 2016;24(4):181-6.

36. Terry Theuri. Summary of a report on the Underlying Causes of Malnutrition in Twic County, Warap State,South Sudan. SSMJ. 2007;1(3). 
Figures

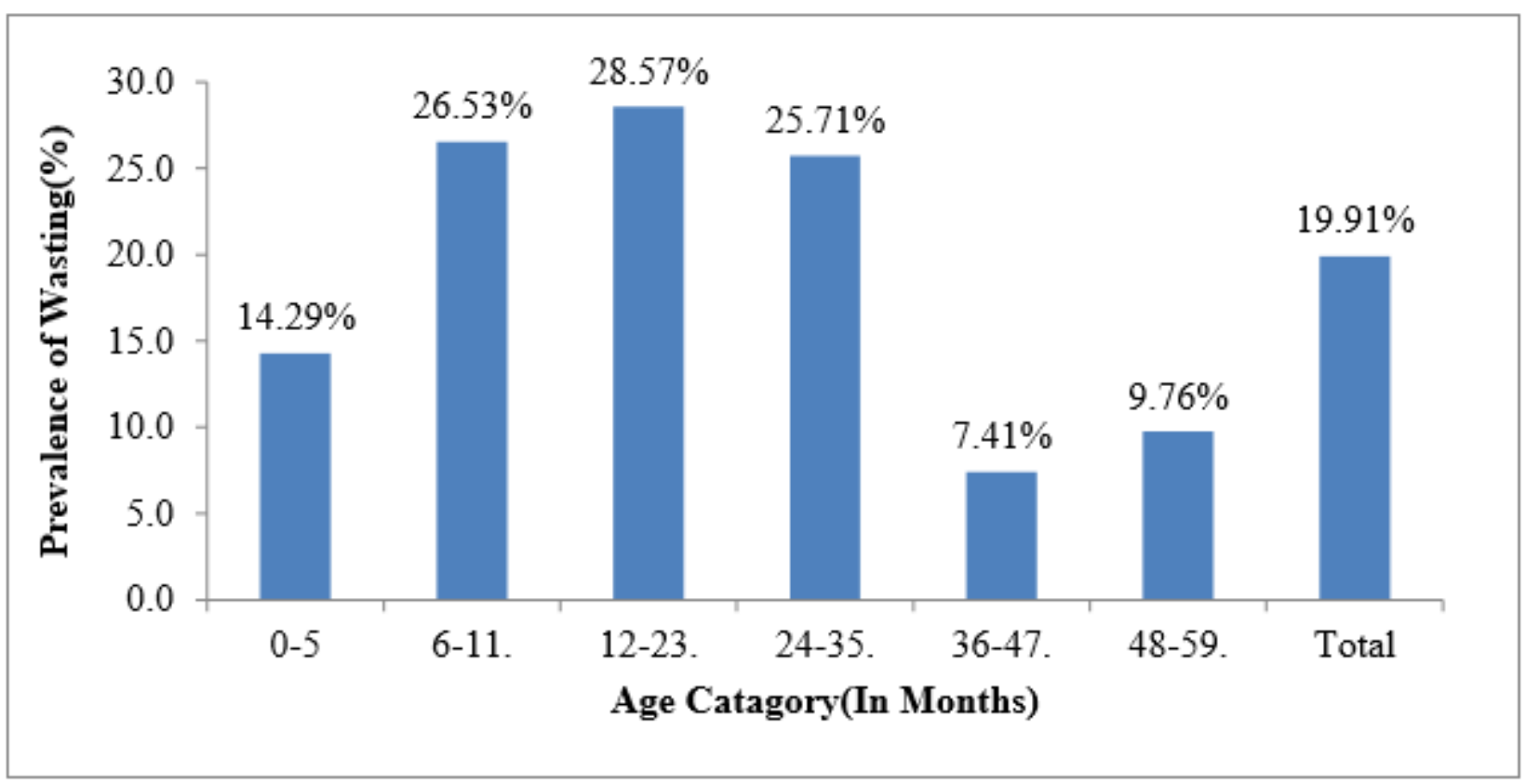

Figure 1

Prevalence of wasting by age among children aged 0-59 months in Shashemene District, West Arsi Zone, Oromia Regional State, Ethiopia, July 2018. 